\section{* \\ BioLegend $^{\oplus}$}

\section{DOI:}

dx.doi.org/10.17504/protocol s.io.tj7ekrn

\section{External link:}

http://www.biolegend.com/m edia_assets/support_protocol/ ChIP_Assay_Technical_Protoc ol_v8̄.pdf

\section{Protocol Citation: Kelsey} Knight . Chromatin Immunoprecipitation (ChIP) Assay Protocol. protocols.io https://dx.doi.org/10.17504/p rotocols.io.tj7ekrn

License: This is an open access protocol distributed under the terms of the Creative Commons Attribution License, which permits unrestricted use, distribution, and reproduction in any medium, provided the original author and source are credited

Created: Sep 13, 2018

Last Modified: Aug 29, 2019

PROTOCOL integer ID: 15711

\section{(i) Chromatin Immunoprecipitation (ChIP) Assay Protocol} V.3

Kelsey Knight $^{1}$

${ }^{1}$ BioLegend

Sam Li

BioLegend

\section{ABSTRACT}

\section{Reagents -}

Basic cell culture media: respective to the cell line used and experimental design Distilled water: Invitrogen ${ }^{\circledR}$ UltraPure ${ }^{\text {TM }}$ Distilled Water (catalog number 19977015) or equivalent product from other vendor.

Highthroughput (HT) Pro A or G 96 well plate or Spin Column (Chromatrap ${ }^{\circledR}$ HT ChIP-qPCR kit; catalog number 500161 or 500162 or 500163)

96-well collection plate: USA scientific ${ }^{\circledR}$ TempPlate non-skirted 96-well PCR plate natural (catalog number 1402-9596) or equivalent product from other vendor. QIAquick ${ }^{\text {mi }}$ PCR purification kit (Qiagen ${ }^{\circledR}$; catalog number 28104) or equivalent product from other vendor.

Hypotonic Buffer (Chromatrap $®$ HT ChIP-qPCR kit; catalog number 500161 or 500162 or 500163)

Digestion Buffer (Chromatrap ${ }^{\circledR}$ HT ChIP-qPCR kit; catalog number 500161 or 500162 or 500163)

Lysis Buffer (Chromatrap ${ }^{\circledR}$ HT ChIP-qPCR kit; catalog number 500161 or 500162 or 500163)

Column Conditioning Buffer (Chromatrap $\AA_{\text {H HT ChIP-qPCR kit; catalog number }}$ 500161 or 500162

or 500163)

Wash Buffer 1 (Chromatrap $\AA^{8}$ HT ChIP-qPCR kit; catalog number 500161 or 500162 or 500163)

Wash Buffer 2 (Chromatrap ${ }^{\circledR}$ HT ChIP-qPCR kit; catalog number 500161 or 500162 or 500163)

Wash Buffer 3 (Chromatrap ${ }^{\circledR}$ HT ChIP-qPCR kit; catalog number 500161 or 500162 or 500163)

Elution Buffer (Chromatrap ${ }^{\circledR}$ HT ChIP-qPCR kit; catalog number 500161 or 500162 or 500163)

5M NaCl: dissolve $292 \mathrm{~g}$ of $\mathrm{NaCl}$ in $800 \mathrm{~mL}$ of $\mathrm{H}_{2} \mathrm{O}$. Adjust the volume to $1 \mathrm{~L}$ with $\mathrm{H}_{2} \mathrm{O}$. $1 \mathrm{M} \mathrm{NaHCO}_{3}$ : dissolve $12.6 \mathrm{~g}$ of $\mathrm{NaHCO}_{3}$ in $100 \mathrm{~mL}$ of $\mathrm{H}_{2} \mathrm{O}$. Adjust the volume to 150 $\mathrm{mL}$ with $\mathrm{H}_{2} \mathrm{O}$.

Protease Inhibitor Cocktail (PIC): Cell signaling Technology ${ }^{\circledR}$ (catalog number 5871) or equivalent product from other vendor.

Proteinase K: Qiagen ${ }^{\circledR}$ (catalog number 19133) or equivalent product from other vendor. 
Proteinase K stop solution: 100mM Phenylmethylsulfonyl fluoride (PMSF). Weigh 1.742g PMSF (Sigma-Aldrich ${ }^{\circledR}$, catalog number 10837091001) and add DMSO (Sigma-Aldrich ${ }^{\circledR}$, catalog number D2650) to a final volume of $100 \mathrm{~mL}$. Dissolve completely.

PBS: HyClone ${ }^{\mathrm{TM}}$ Phosphate Buffered Saline (1X) (catalog number SH30256.01) or equivalent product from other vendor.

Formaldehyde: VWR® $37 \% \mathrm{w} / \mathrm{w}$ aqueous solution (catalog number $97064-604$ ) or equivalent product from other vendor.

0.65M Glycine: Dissolve $488 \mathrm{~g}$ of glycine into $1 \mathrm{~L}$ of $\mathrm{H}_{2} \mathrm{O}$ to make $6.5 \mathrm{M}$ glycine (10X). Dilute with PBS to make $1 \mathrm{X}$ before each experiment.

Micrococcal Nuclease: Cell Signaling Technologies ${ }^{\circledR}$ (catalog number 10011S) or equivalent product from other vendor.

1.3-1.5\% Agarose gel: dissolve 1.3-1.5g of agarose powder into $100 \mathrm{~mL}$ of TAE buffer by microwave heating. Visualize DNA under UV light by adding appropriate amount of Ethidium Bromide, or use an equivalent method.

Add appropriate amount of Ethidium Bromide to cooled down gel solution to visualize DNA under UV light.

0.5M EDTA: Dissolve $186.1 \mathrm{~g}$ EDTA into $700 \mathrm{~mL}$ of $\mathrm{H}_{2} \mathrm{O}$. Adjust the volume to $1 \mathrm{~L}$ with $\mathrm{H}_{2} \mathrm{O}$.

100bp ladder: $N E B \AA$ (catalog number N0467S) or equivalent product from other vendor.

\author{
Materials - \\ Heat block \\ Rotator \\ Centrifuge \\ Microcentrifuge \\ $37^{\circ} \mathrm{C}$ incubator \\ Nanodrop \\ Sonicator \\ UV light imager \\ Rocking platform
}

\title{
Chromatin Sample Preparation
}

1 Culture between 1-15 million cells. Collect cells by spinning down at $500 \times \mathrm{xg}$ at $4^{\circ} \mathrm{C}$ for 5 minutes. Wash cells with PBS at room temperature.

(3) 00:05:00

2 Remove the PBS and add freshly made basic cell culture media (it should not contain any serum or large molecular weight proteins to avoid any interferences from those proteins) containing $1 \%$ formaldehyde $\left(\mathrm{CH}_{2} \mathrm{O}\right)$ to cross-link the DNA-protein complexes. 
3 Incubate for 10 minutes at room temperature with gentle agitation on a rocking platform.

\section{(3) 00:10:00}

4 Remove the fixation solution by spinning down at $500 \mathrm{xg}$ at $4^{\circ} \mathrm{C}$ for 5 minutes. To quench there action, for cell count of 1-5 million, add $3 \mathrm{~mL}$ of $0.65 \mathrm{M}$ glycine solution; for cell count of $5-10$ million, add $4 \mathrm{~mL}$ of $0.65 \mathrm{M}$ glycine solution; for cell count of $10-15$ million, add $5 \mathrm{~mL}$ of $0.65 \mathrm{M}$ glycine solution.

\section{0:05:00}

5 Incubate at room temperature for 5 minutes with gentle agitation on a rocking platform.

\section{(7) 00:05:00}

6 Remove the glycine solution by spinning down at $500 \mathrm{xg}$ at $4^{\circ} \mathrm{C}$ for 5 minutes. Discard the supernatant. The pellet can be frozen at $-80^{\circ} \mathrm{C}$ after adding $1 \mu \mathrm{L}$ of Protease Inhibitor Cocktail (PIC).

\section{0:05:00}

7 To lyse the cells, for cell count of 1-5 million, add $0.4 \mathrm{~mL}$ of Hypotonic Buffer; for cell count of 510 million, add $0.8 \mathrm{~mL}$ of Hypotonic Buffer; for cell count of $10-15$ million, add $1 \mathrm{~mL}$ of Hypotonic Buffer to the cell pellet. Resuspend the cells and incubate at $4^{\circ} \mathrm{C}$ for 10 minutes.

\section{(3) 00:10:00}

8 Centrifuge the hypotonic slurries at $5,000 \times \mathrm{xg}$ at $4^{\circ} \mathrm{C}$ for 5 minutes to collect the nuclei.

\section{(3) 00:05:00}

9 For cell count of 1-5 million, add $0.3 \mathrm{~mL}$ of Digestion Buffer; for cell count of 5-10 million, add $0.4 \mathrm{~mL}$ of Digestion Buffer; for cell count of $10-15$ million, add $0.5 \mathrm{~mL}$ of Digestion Buffer to the nuclei, immediately followed by adding $2 \mu \mathrm{L}$ of PIC to each sample.

10 Add Micrococcal Nuclease to each sample to digest the DNA. Mix by inverting the tube several times and incubate at $37^{\circ} \mathrm{C}$ for 20 minutes. Mix by inversion every 3-5 minutes. The amount and incubation time of Micrococcal Nuclease required to digest the genomic DNA to an optimal 150 900 bp length may need to be determined empirically for individual cell types.

\section{(3) 00:20:00}

11 Stop digestion by adding $10 \mu \mathrm{L}$ of $0.5 \mathrm{M}$ EDTA per sample and place the sample on ice. 
12 Pellet nuclei by centrifugation at $12,000 \times \mathrm{xg}$ at $4^{\circ} \mathrm{C}$ for 1 minute. Discard the supernatant.

(3) 00:01:00

13 Resuspend nuclear pellet in Lysis Buffer and incubate the sample on ice for 10 minutes to lyse the nuclei. Alternatively, sonicate to shear the DNA. The time and strength for sonication may need to be determined empirically.

\section{(3) 00:10:00}

14 Centrifuge the sample at $16,000 \times \mathrm{xg}$ at $4^{\circ} \mathrm{C}$ for 10 minutes. Transfer the supernatant to a clean dry microcentrifuge tube.

\section{(7) 00:10:00}

15 Add $1 \mu \mathrm{L}$ of PIC to each sample and mix.

16 Chromatin sample is now ready for ChIP Assay. If the sample is not to be used immediately, store at $-80^{\circ} \mathrm{C}$. It is recommended that the shearing efficiency is analyzed at this stage to ensurethat 150-900bp fragments are obtained during shearing the DNA to increase the ChIP efficiency.

\section{Addendum: Shearing Efficiency Analysis}

17 Take $50 \mu \mathrm{L}$ aliquot of sheared chromatin from each sample into a new microcentrifuge. Add $5 \mu \mathrm{Lof} 1 \mathrm{M} \mathrm{NaHCO}_{3}, 5 \mu \mathrm{L}$ of $5 \mathrm{M} \mathrm{NaCl}$ and $50 \mu \mathrm{L}$ of Distilled Water. Mix thoroughly and incubate at $65^{\circ} \mathrm{C}$ (heat block) for two hours or incubation can be extended for overnight.

\section{(3) 02:00:00}

18 Remove the sample from heat block, add $1 \mu \mathrm{L}$ of Proteinase $\mathrm{K}$ to each sample, vortex briefly and perform a spin down at $500 \mathrm{xg}$ at $4^{\circ} \mathrm{C}$ for 5 minutes. Incubate at $37^{\circ} \mathrm{C}$ for one hour.

\section{(3) 01:00:00}

19 Add $2 \mu \mathrm{L}$ of Proteinase K Stop Solution to each sample, vortex briefly and perform a short spin down. 
21 Quantify the DNA in the sample using a Nanodrop. This will be used to determine the volume of chromatin to load in ChIP assay.

22 To ensure 150-900bp fragments have been obtained during shearing the DNA, run each DNA sample on a 1.3-1.5\% agarose gel and visualize against a marker of known size DNA fragments (e.g., 100bp ladder).

\section{Chromatin Immunoprecipitation Assay}

23 Mix the Chromatin Sample, Protease Inhibitor Cocktail (PIC), optimal quantity of BioLegend's GoChIP-Grade ${ }^{\mathrm{TM}}$ Purified antibodies and add Column Conditioning Buffer to make final $1 \mathrm{~mL}$ slurries. Gently rotate at $4^{\circ} \mathrm{C}$ for one hour or incubation can also be extended to overnight.

\section{1:00:00}

24 Prepare the high-throughput (HT) Protein A or G 96 well plate or Spin Column by adding $600 \mu \mathrm{L}$ of Column Conditioning Buffer in each well or column and allow it to flow through via gravity ( 15 minutes).

\section{(7) 00:15:00}

25 Discard the flow-through and repeat steps 24 and 25.

26 Remove the slurries from the rotator following $4^{\circ} \mathrm{C}$ incubation and briefly spin down to remove residual liquid from the caps.

27 Load the entire $1 \mathrm{~mL}$ slurries and allow to flow completely through the high-throughput (HT) Protein A or G 96 well plate or Spin Column at room temperature (approximate 15-20 minutes).

\section{(3) $00: 20: 00$}

28 Add $600 \mu \mathrm{L}$ of Wash Buffer 1 to each well or column and centrifuge at $2000 \mathrm{xg}$ for plate, or $4000 x g$ for column, for one minute at room temperature. Discard the flow through and repeat once. 
29 Add $600 \mu \mathrm{L}$ of Wash Buffer 2 to each well or column and centrifuge at $2000 \mathrm{xg}$ for plate, or $4000 x g$ for column, for one minute at room temperature. Discard the flow through and repeat once.

\section{(3) 00:01:00}

30 Add $600 \mu \mathrm{L}$ of Wash Buffer 3 to each well or column and centrifuge at $2000 \mathrm{xg}$ for plate, or $4000 x g$ for column, for one minute at room temperature. Discard the flow through and repeat once.

\section{(3) 00:01:00}

31 Spin dry at $4,000 \mathrm{xg}$ for the plate or $16,000 \mathrm{xg}$ for the column for one minute at room temperature to remove any remaining liquid from the membrane of the plate or column. Place a clean 96 well collection plate or a collection tube beneath the plate or column.

\section{0:01:00}

32 Add $50 \mu \mathrm{L}$ of Elution Buffer to each well or column. Incubate at room temperature for 15 minutes. (3) 00:15:00

33 Centrifuge the plate or column at 4,000xg for the plate, or $16,000 \times \mathrm{xg}$ for the column, for one minute at room temperature to collect the eluted chromatin-protein complex.

\section{(3) 00:01:00}

34 To each eluted sample, add $5 \mu \mathrm{L}$ of $1 \mathrm{M} \mathrm{NaHCO}_{3}, 5 \mu \mathrm{L}$ of $5 \mathrm{M} \mathrm{NaCl}$ and $50 \mu \mathrm{L}$ of Distilled Water. Mix thoroughly and incubate at $65^{\circ} \mathrm{C}$ on the heat block for two hours or the incubation time can be extended to overnight.

(3) $02: 00: 00$

35 Remove the sample from the heat block, add $1 \mu \mathrm{L}$ of Proteinase $\mathrm{K}$ to each sample, vortex briefly and perform a short spin down. Incubate at $37^{\circ} \mathrm{C}$ for one hour.

\section{(3) 01:00:00}

36 Add $2 \mu \mathrm{L}$ of Proteinase $\mathrm{K}$ Stop Solution to each sample, vortex briefly and perform a short spin down.

37 Purify the DNA by QIAquick ${ }^{\mathrm{TM}}$ PCR purification kit, according to manufacturer's manual. Purified DNA is ready for downstream real-time qPCR analysis. 
